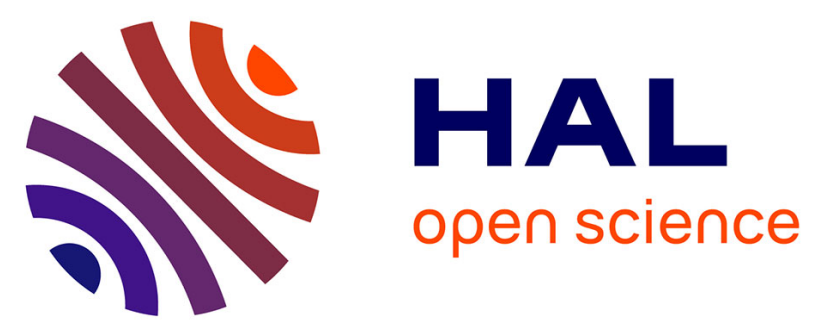

\title{
PRKAG3 and CAST genetic polymorphisms and quality traits of dry-cured hams-II. Associations in french dry-cured ham jambon de bayonne and their dependence on salt reduction.
}

Veronique Sante-Lhoutellier, Nathalie Robert, Jean-Francois Martin, Pere

Gou, M. Hortós, J. Arnau, A. Diestre

\section{To cite this version:}

Veronique Sante-Lhoutellier, Nathalie Robert, Jean-Francois Martin, Pere Gou, M. Hortós, et al.. PRKAG3 and CAST genetic polymorphisms and quality traits of dry-cured hams-II. Associations in french dry-cured ham jambon de bayonne and their dependence on salt reduction.. Meat Science, 2012, 92 (4), pp.354-359. 10.1016/j.meatsci.2012.06.022 . hal-02651216

\author{
HAL Id: hal-02651216 \\ https://hal.inrae.fr/hal-02651216
}

Submitted on 29 May 2020

HAL is a multi-disciplinary open access archive for the deposit and dissemination of scientific research documents, whether they are published or not. The documents may come from teaching and research institutions in France or abroad, or from public or private research centers.
L'archive ouverte pluridisciplinaire HAL, est destinée au dépôt et à la diffusion de documents scientifiques de niveau recherche, publiés ou non, émanant des établissements d'enseignement et de recherche français ou étrangers, des laboratoires publics ou privés. 


\title{
PRKAG3 and CAST genetic polymorphisms and quality traits of dry-cured hams-II. Associations in French dry-cured ham Jambon de Bayonne and their dependence on salt reduction
}

\author{
V. Santé-Lhoutellier ${ }^{\text {a,* }}$, N. Robert ${ }^{\text {b }}$, J.F. Martin ${ }^{\text {c }}$, P. Gou ${ }^{\text {d }}$, M. Hortós ${ }^{\text {d }}$, J. Arnau ${ }^{\text {d }}$, \\ A. Diestre ${ }^{\mathrm{e}}, \mathrm{M}$. Candek-Potokar ${ }^{\mathrm{f}}$ \\ a INRA, UR 370 QuaPA, 63122 Saint Genès Champanelle, France \\ b INPAQ 64410 Arzacq, France \\ ' INRA, UMR UNH, 63122 Saint Genès Champanelle, France \\ d IRTA, Food Technology, XaRTA, Finca Camps i Armet, 17121 Monells, Spain \\ e PIC Spain, Avda. Ragull 80, 08173 St Cugat Del Vallés, Spain \\ ${ }^{\mathrm{f}}$ Agricultural Institute of Slovenia, Hacquetova ulica 17, 1000 Ljubljana, Slovenia
}

\section{A R T I C L E I N F O}

\section{Article history:}

Received 2 March 2012

Received in revised form 11 June 2012

Accepted 12 June 2012

\section{Keywords:}

Dry-cured ham

Salt reduction

CAST

PRKAG3

Rheological traits

Sensory traits

\begin{abstract}
A B S T R A C T
This study aimed to evaluate the effects of PRKAG3 Ile199Val and CAST Arg249Lys and CAST Ser638Arg polymorphisms on the quality traits of the French dry-cured ham Jambon de Bayonne and their interaction with salt reduction. Significant $(p<0.05)$ and suggestive associations $(p<0.10)$ between the polymorphisms and several quality traits of dry-cured ham, mainly related to processing and textural properties, were found. PRKAG3 Ile/Val and CAST 249Lys/638Arg presented the highest scores for sensory and processing properties, whatever the salt content.
\end{abstract}

(c) 2012 Elsevier Ltd. All rights reserved.

\section{Introduction}

Salting has a long history as a traditional food preservation process, but consumers are now increasingly aware of the deleterious effects of salt intake on their health. Salt can increase blood pressure, thus increasing the risk of cardiovascular disease. Consequently, there is a strong demand for reduced-salt food to meet nutritional recommendations. As dry-cured ham is a popular meat product in many European countries, decreasing its salt content takes on great importance. In France, since 1998, the dry-cured ham Jambon de Bayonne has EU Protected Geographical Indication (PGI) status, which guarantees products made according to traditional methods in specific areas of origin. Moreover, this certification requires professional processors to comply with specifications that provide the consumer with a finished product of optimal quality, particularly in terms of texture.

Curing is a technological process based on adding salt and nitrate and/or nitrite on the ham's external surface to act as preserving agents, but it also has physicochemical and biochemical effects that

\footnotetext{
* Corresponding author. Tel.: +33 473624708 .

E-mail address: veronique.sante@clermont.inra.fr (V. Santé-Lhoutellier).
}

contribute to the development of the textural and flavour properties. Salt affects muscle proteins by inducing denaturation (Adamsen, Moller, Parolari, Gabba, \& Skibsted, 2006; Graiver, Pinotti, Califano, \& Zaritzky, 2006), the extent of which is dependent on salt concentration (Thorarinsdottir, Arason, Geirsdottir, Bogason, \& Kristbergsson, 2009) and processing yields (Santé-Lhoutellier, Candek-Potokar, Gou, Dutertre, \& Robert, 2009). In dry-cured ham, proteolysis occurs throughout processing, but at different rates and to varying extents depending on salt penetration and water migration, with greater proteolytic activity in the biceps femoris muscle compared to the semimembranosus muscle ultimately affecting its texture (Parolari, Virgili, \& Schivazappa, 1994; Rosell \& Toldrá, 1998; Théron, Chevarin, Robert, Dutertre, \& Santé-Lhoutellier, 2009; Théron et al., 2011; Virgili, Parolari, Schivazappa, Bordini, \& Borri, 1995; Virgili, Schivazappa, Parolari, Bordini, \& Degni, 1998). Proteolytic activity in dry-cured ham is essentially attributed to cathepsins, which act for a longer period (Sárraga, Gil, Arnau, Monfort, \& Cussó, 1989; Toldrá \& Flores, 1998). However, the first stage of processing also involves classical muscle ageing, when calpains can act (Théron et al., 2011). Recently, Benedini, Parolari, Toscani, and Virgili (2012) concluded that salt content in traditional Italian dry-cured ham could only be lowered by keeping strict process control over environmental 
conditions, especially temperature, in order to limit proteolytic enzyme activity.

The challenge today in pig selection is to adapt breedlines and crossbreeds to ultimate meat use. Garnier, Klont, and Plastow (2003) made an inventory of genetic markers associated with certain quality traits of fresh meat. DNA markers for meat quality have been identified (Plastow et al., 2005; Stefanon et al., 2004). Stalder, Rothshild, and Lonergan (2005) evaluated the effect of calpastatin gene polymorphism on US dry-cured ham. Processing times are generally shorter in the US than in European countries. The polymorphism concerns two nucleotide mutations (Arg249Lys and Ser638Arg) of calpastatin, which were associated with pork meat texture (Ciobanu et al., 2004). The authors demonstrated that the CAST genotype marker significantly influenced cured ham moisture content, prompting them to conclude that selection for this CAST genotype would produce cured hams having more efficient moisture loss, thus requiring less processing time. Among several candidate genes, the PRKAG3 gene, and more specifically the Ile199Val polymorphism, is interesting as it affects ultimate $\mathrm{pH}$ in the muscle (Ciobanu et al., 2001). The PRKAG3 gene codes for the $\gamma$ subunit of the adenosine monophosphate-dependent protein kinase, an enzyme that plays a key regulatory role in muscle cell energy metabolism. Škrlep et al. (2010) recently demonstrated the importance of $\mathrm{pH}$ of green ham for proteolysis, concluding that a lower $\mathrm{pH}$ would favour cathepsin activity.

This work is part of the EC 6th Framework Programme "TRUEFOOD” project studying the effect of PRKAG3 and CAST gene polymorphisms on the quality of the dry-cured hams produced in Spain, France and Slovenia using specific raw materials and processing conditions. The aim of the paper, which is the second of a series of three papers, is to evaluate the feasibility of selecting animals by using CAST and PRKAG3 gene polymorphisms to produce dry-cured Jambon de Bayonne hams with normal and reduced salt contents.

\section{Material and methods}

\subsection{Animals and green ham evaluations}

Thirteen batches of pigs (PIC $410 \times$ C25 crossbreed) were slaughtered at a commercial abattoir (FIPSO Aquitaine, Lahontan), and batch number, date of slaughter, sex, carcass classification, and carcass and ham traceability data were recorded for each animal. At $24 \mathrm{~h}$ after slaughter, the hams were cut off the carcass, trimmed into a prescribed shape, and selected according to Bayonne ham consortium specifications, i.e. green ham weight $>9.5 \mathrm{~kg}$, fat thickness $>10 \mathrm{~mm}$, and visual appearance (no PSE or DFD hams, no skin lacerations, blood spots, haematomas or excessive superficial veining). Ham fat thickness was measured on trimmed ham below the caput ossis femoris. $\mathrm{pH}$ was measured in the semimembranosus muscle at $24 \mathrm{~h}$ post mortem. Sensorial colour grade was evaluated on the vastus lateralis muscle according to the 1-6 score on the Japanese colour scale. These results were published by Škrlep et al. (2010).

\subsection{Genotype determination}

A small piece of ear from each carcass was taken at the abattoir $(n=559)$ and frozen in liquid nitrogen for genotyping. Samples were genotyped using the PCR-RFLP method according to Ciobanu et al. $(2001,2004)$ for PRKAG3 Ile199Val, CAST Arg249Lys and CAST Ser638Arg polymorphisms.

\subsection{Ham processing and yield}

A total of 1118 hams were lined up for processing according to PGI Jambon de Bayonne specifications. The two hams of each pig were subjected to different times of salting to achieve a roughly $20 \%$ reduction in sodium content. Duration of salting was adapted to the weight of the ham (Table 1). Temperature was kept in the range of $2.5^{\circ} \mathrm{C}$ to $3{ }^{\circ} \mathrm{C}$.

After salting, the hams were washed with water and left to rest for 12 weeks in a chamber at $4{ }^{\circ} \mathrm{C}$ and $68-76 \% \mathrm{RH}$. Following the resting period, the hams were dried for $21 / 2$ months by progressively increasing the temperature up to $15^{\circ} \mathrm{C}$ while reducing the relative humidity from $74 \%$ to $66 \%$. Thereafter, the exposed surface was covered with a mixture of pork fat and flour to prevent desiccation of the surface. Finally, the hams were ripened for 12 months in a dryerchamber at $18{ }^{\circ} \mathrm{C}$ and $60-67 \% \mathrm{RH}$. All hams were weighed to record weight losses at different processing stages (end of salting, end of resting, end of ripening). After deboning, the hams were moulded in an automatic press (pressure/vacuum cycles) to obtain bricks of dry-cured hams ready to be sliced. The hams were then sliced in industrial conditions, and slicing yield was recorded.

\subsection{Analysis of processed ham}

At the end of processing, a total of 559 hams had been correctly processed and genotyped. A subsample of 120 hams (60 carcasses) was selected, taking into account processing batch and polymorphisms PRKAG3 Ile199Val, CAST Arg249Lys and CAST Ser638Arg, to perform physicochemical and sensorial analyses on the biceps femoris muscle. Proximate composition of the dry-cured ham was determined based on the following measures: moisture by drying at $104{ }^{\circ} \mathrm{C}$ for $48 \mathrm{~h}$; $\mathrm{NaCl}$ content by the Charpentier-Volhard method based on chloride determination (ISO-1841-1, 1996); fat content (\%) by the Soxhlet method (ISO-1443, 1973); total nitrogen by the Kjeldahl method (SI-937, 1978), and expressed as percent protein content $(\mathrm{TN} \times 6.25)$; non-protein nitrogen content $(\mathrm{NPN})$ by protein precipitation with trichloroacetic acid (Kerese \& Chalmers, 1984) followed by determination of nitrogen by the Kjeldahl method; lipid oxidation by the thiobarbituric acid reactive substance (TBARS) assay (Shahidi, Rubin, Diosady, \& Wood, 1985). A proteolysis index (PI) was calculated by the formula IP $=100 \times \mathrm{NPN} / \mathrm{TN}$.

\subsection{Sensory analysis}

Sensory evaluation was carried out by a panel of 12 assessors trained according to the standards ISO 85861 and ISO 13299. Samples were randomly distributed to different session days according to processing batch, salt content, and genotype. In each session, six ham samples ( 3 pairs of ham) were evaluated based on the descriptors below, which were scored on a non-structured 0-6 point scale, where 0 indicates absence of the descriptor and 6 indicates maximum intensity.

Descriptors of appearance were recorded for the whole slice, on the presented face without turning it over: quantity of fat between muscles, intensity of the red colour, iridescence (colours of the rainbow), marbling (quantity of fat infiltration), crustiness (harder and darker circumference), heterogeneous colour (evaluation of the spots of various colours), and oiliness (shiny as if covered in an oil film).

Descriptors of odour were recorded for the whole slice, on the presented face without turning it over: total odour intensity, raw meat odour, spicy odour, pungent odour, and other odour (than those quoted above).

Table 1

Duration of salting according to green ham weight.

\begin{tabular}{lll}
\hline & Duration of salting & \\
\cline { 2 - 3 } & Normal & Low \\
\hline $9.5-10.5 \mathrm{~kg}$ & 11 days & 8 days \\
$10.5-11.5 \mathrm{~kg}$ & 13 days & 11 days \\
\hline
\end{tabular}


Descriptors of taste and texture were evaluated separately on semimembranosus (SM) and biceps femoris (BF): easy to cut (resistance to slicing with a knife), easy to chew, tenderness, fibrousness, pastiness (mouth coating sensation produced by flour-water paste during mastication), dryness, presence of crystals (grittiness), persistence of fat, salty taste, acid taste, bitter taste, global taste intensity, rancid flavour, and lingering of the taste.

\subsection{Statistical analysis}

An analysis of variance was performed using the MIXED procedure of SAS. The linear model included the gene polymorphisms and salt (normal and low) as fixed effects, batch and carcass as random effects, and fresh ham weight as a covariate. For sensory traits, the model also included session as a random effect. Where there was a significant effect of gene polymorphism, least squares means were compared using LSMEANS with Tukey's test option. Genotype and salt effects are presented separately in tables when no interactions were significant.

CAST haplotypes were also compared. The haplotypes inferred between CAST249 and CAST638, i.e. 249Lys-638Arg, 249Arg-638Arg, 249Arg-638Ser and 249Lys-638Ser, were analysed by considering animals (hams) as having 0,1 or 2 copies of the haplotype-of-interest. The models used were equivalent to those applied for single polymorphisms, including the combined CAST249-CAST638 genotype instead of the single CAST gene polymorphisms.

\section{Results and discussion}

\subsection{PRKAG3 Ile199Val, CAST Arg249Lys and CAST Ser638Arg distribution}

Genotype distribution by gene markers is presented in Table 2. For PRGAG3, Ile/Ile was found at low frequency compared to Ile/Val and $\mathrm{Val} / \mathrm{Val}$. Similarly, for CAST at locus 249 and CAST at locus 638, Arg/ Arg and Ser/Ser were underrepresented, respectively.

\subsection{Effect of salt reduction in dry cured hams}

Salt reduction had effects on practically every item studied except lipid and protein contents (Table 3 ). The average salt reduction achieved was 15 to $20 \%$. Higher moisture and proteolysis indexes were noted in dry cured hams with less salt.

Lipid oxidation was lower in the reduced-salt-content ham. Most of the lipolysis takes place during the first 5 months of dry-cured ham production, generating free fatty acids and especially mono- or polyunsaturated fatty acids prone to oxidation (Ripolles, Campagnol, Armenteros, Aristoy, \& Toldrá, 2011). Salt plays an important role in controlling enzyme activity, as less salt leads to increased water activity in the product. However, unlike mainly muscle enzymes, lysosomal acid lipase showed higher activity with higher salt concentration and lower water activity (Motilva \& Toldrá, 1993). Recently, Ripolles et al. (2011) reported that partially replacing the sodium chloride in dry-cured ham resulted in almost equal lipid oxidation. Proteolysis index was higher in dry-cured ham with reduced salt content, as

Table 2

Genotype distribution by gene markers in the genotyped population $(n=559)$ and distribution breakdown.

\begin{tabular}{llll}
\hline \multicolumn{4}{l}{ Genotype frequencies } \\
\hline PRKAG3 Ile199Val & Ile/Ile & Ile/Val & Val/Val \\
& 0.038 & 0.566 & 0.395 \\
CAST Arg249Lys & Arg/Arg & Arg $/$ Lys & Lys/Lys \\
& 0.081 & 0.555 & 0.363 \\
CAST Ser638Arg & Ser/Ser & Ser/Arg & Arg/Arg \\
& 0.015 & 0.455 & 0.530 \\
\hline
\end{tabular}

\section{Table 3}

Association between salt content and physicochemical, processing and sensory traits. For sensory traits only significant $(\mathrm{p}<0.05)$ or suggestive $(\mathrm{p}<0.10)$ associations are shown. Least squares means \pm standard error.

\begin{tabular}{lrrl}
\hline & \multicolumn{1}{c}{ Low salt } & Normal salt & p Value \\
\hline Physicochemical traits & & & \\
Moisture (\%) & $60.40 \pm 0.26$ & $59.57 \pm 0.25$ & 0.001 \\
Chloride (\%) & $5.37 \pm 0.15$ & $6.16 \pm 0.15$ & 0.001 \\
Protein content (\%) & $29.34 \pm 0.23$ & $29.55 \pm 0.22$ & NS \\
Lipid (\%) & $3.24 \pm 0.32$ & $3.26 \pm 0.31$ & NS \\
Proteolysis index (\%) & $29.40 \pm 0.61$ & $28.32 \pm 0.60$ & 0.007 \\
TBARS (mg MDA/kg) & $0.59 \pm 0.08$ & $0.74 \pm 0.07$ & 0.047 \\
Processing traits & & & \\
Salting loss (\%) & $3.90 \pm 0.12$ & $4.60 \pm 0.11$ & 0.001 \\
Resting loss (\%) & $20.70 \pm 0.50$ & $21.24 \pm 0.50$ & 0.008 \\
Ripening loss (\%) & $31.49 \pm 0.72$ & $31.85 \pm 0.71$ & 0.088 \\
Processing yield (\%) & $68.85 \pm 0.59$ & $68.77 \pm 0.57$ & NS \\
Slicing yield (\%) & $87.23 \pm 0.52$ & $86.80 \pm 0.49$ & NS \\
& & &
\end{tabular}

Sensory traits ${ }^{\mathrm{a}}$

Semimembranosus muscle

Grittiness

Persistence of fat

Global taste intensity

Rancid flavour

Fibrousness

Salty taste

Pastiness

Tenderness

Biceps femoris muscle

Easy to chew

Persistence of fat

Dryness

Fibrousness

Rancid flavour

Salty taste

Pastiness

Tenderness

$\begin{array}{lll}0.11 \pm 0.01 & 0.15 \pm 0.01 & 0.01 \\ 3.03 \pm 0.09 & 3.17 \pm 0.09 & 0.02 \\ 3.71 \pm 0.06 & 3.89 \pm 0.06 & 0.01 \\ 0.21 \pm 0.02 & 0.16 \pm 0.02 & 0.07 \\ 1.61 \pm 0.09 & 1.72 \pm 0.09 & 0.10 \\ 2.71 \pm 0.07 & 3.03 \pm 0.06 & 0.001 \\ 2.70 \pm 0.54 & 2.11 \pm 0.55 & 0.019 \\ 3.83 \pm 0.10 & 3.64 \pm 0.10 & 0.019 \\ & & \\ 4.36 \pm 0.09 & 4.13 \pm 0.09 & 0.004 \\ 3.04 \pm 0.09 & 3.21 \pm 0.09 & 0.01 \\ 2.51 \pm 0.10 & 2.80 \pm 0.09 & 0.0006 \\ 0.94 \pm 0.10 & 1.10 \pm 0.10 & 0.08 \\ 0.32 \pm 0.04 & 0.26 \pm 0.04 & 0.09 \\ 2.66 \pm 0.08 & 3.01 \pm 0.08 & 0.0001 \\ 1.71 \pm 0.46 & 1.36 \pm 0.45 & 0.07 \\ 4.14 \pm 0.11 & 3.91 \pm 0.10 & 0.008\end{array}$

a $0-10$ points non-structured scale ( 0 : absence; 10 : maximum intensity).

expected, but interestingly, salt reduction did not impact processing yield or quantity of saleable product.

Generally speaking, the effect of salt reduction on sensory traits affected both SM and BF muscles in much the same way, independently of muscle structure and salt/water dynamics. Higher salt content was always associated with greater intensity and duration of overall taste in dry-cured ham. Conversely, lower salt content reduced the effort needed to chew the dry-cured ham, and consequently increased product tenderness and, to some extent, pastiness. Fibrousness was also slightly reduced in lower-salt ham. Benedini et al. (2012) recently demonstrated the role of salt content as a promoter of odour and taste by evaluating the impact of salt content (low, intermediate and high) on the sensory traits of dry-cured ham. To avoid mixed effects of volatile compounds coming from intramuscular fat oxidation, the fat trait was included in the model as a covariate. Matured odour and taste increased with salt content, whereas green meat odour or taste was unaffected by salt content. The disappearance of the sensory item associated to raw meat is largely dependent on the duration of meat ageing. Here, all the dry-cured hams were ripened for a similar 12-month period. The grittiness was less important in the reduced-salt-content hams, but only in the SM muscle. The presence of crystals is often attributed to the release of free amino acids, especially tyrosine due to excess of proteolysis. Another source of crystal on dry cured ham surface was reported by Arnau, Maneja, Guerrero, and Monfort (1993) but there it was a matter of phosphate crystals increased by higher salt. In a Slovenian study (Škrlep et al., 2012) on Kraški pršut, free tyrosine measurements were highest in the higher-water-content hams having the highest proteolysis index (from producer B). Compared to different studies on Iberian and Italian dry-cured ham, the present study shows that salt reduction has an overall positive effect on sensory traits. Martin, Cordoba, 
Antequera, Timon, and Ventanas (1998) and Virgili et al. (1995) highlighted the side effects of lower salt, especially an increase in non-protein nitrogen which is often associated with defective appearance (presence of a white surface film) and an increased percentage of mushy mouthfeel.

\subsection{Association between PRKAG3 Ile199Val and physicochemical, processing and sensory traits}

Table 4 reports the association of PRKAG3 with physicochemical and processing traits, which in both cases remained very limited. Ile/Ile homozygotes presented a slightly higher moisture content compared to $\mathrm{Val} / \mathrm{Val}$ homozygotes. Stalder et al. (2005) did not report differences in moisture content, probably because country-style drycured ham is processed differently from Mediterranean-style drycured ham which is ripened for longer periods. Processing traits were unaffected by PRKAG3 polymorphism. The PRKAG3 gene had no effect on weight loss during processing or on processing and slicing yields. Such processing traits are generally correlated to several fresh pork quality traits (Ramos, Serenius, Stalder, \& Rothschild, 2007). Fontanesi et al. (2008) previously reported an absence of effect on ultimate $\mathrm{pH}$ of the PRKAG3 gene mutation at locus 199, but they also found that PRKAG3 significantly affected the rate of $\mathrm{pH}$ drop in $\mathrm{Val} / \mathrm{Val}$ genotype animals. They also tested other mutations for PRKAG3, i.e. T30N and G52S, but neither of them were associated with the extent of $\mathrm{pH}$ decline. In general, the Ile/Ile homozygotes yield a slightly higher ultimate $\mathrm{pH}$, which is not different from the Ile/Val heterozygotes or $\mathrm{Val} / \mathrm{Val}$ homozygotes (Otto et al., 2007; Stalder et al., 2005). Škrlep et al. (2010) recently highlighted the importance of the site of measurement for ultimate $\mathrm{pH}$ in the semimembranosus from Slovenian dry-cured ham Kraški pršut. The authors demonstrated a PRKAG3 gene effect on ultimate $\mathrm{pH}(\mathrm{pHu})$ when the measurements were taken at the part adjacent to the femur bone, while in the Spanish line used for Serrano ham, they reported that the homozygous Ile/Ile line led to a slightly but

Table 4

Association between physicochemical, processing, sensory traits of Bayonne dry cured ham and PRKAG3 Ile199Val genotype. Least squares means \pm standard error. For sensory traits only significant $(\mathrm{p}<0.05)$ or suggestive $(\mathrm{p}<0.10)$ associations are shown.

\begin{tabular}{|c|c|c|c|c|}
\hline & \multicolumn{4}{|c|}{ PRKAG3 Ile199Val genotypes } \\
\hline & $\begin{array}{l}\text { Ile/Ile } \\
n=26\end{array}$ & $\begin{array}{l}\text { Ile/Val } \\
n=48\end{array}$ & $\begin{array}{l}\text { Val/Val } \\
n=46\end{array}$ & $\mathrm{p}$ Value \\
\hline \multicolumn{5}{|l|}{ Physicochemical traits } \\
\hline Moisture (\%) & $60.49 \pm 0.36$ & $59.68 \pm 0.36$ & $59.79 \pm 0.31$ & 0.07 \\
\hline Chloride (\%) & $5.63 \pm 0.19$ & $5.74 \pm 0.19$ & $5.92 \pm 0.17$ & NS \\
\hline Protein content (\%) & $29.15 \pm 0.31$ & $29.56 \pm 0.31$ & $29.62 \pm 0.26$ & NS \\
\hline Lipid (\%) & $3.35 \pm 0.43$ & $3.41 \pm 0.42$ & $2.98 \pm 0.37$ & NS \\
\hline Proteolysis index (\%) & $28.24 \pm 0.75$ & $29.37 \pm 0.74$ & $28.98 \pm 0.67$ & NS \\
\hline TBARS (mg MDA/kg) & $0.73 \pm 0.10$ & $0.62 \pm 0.10$ & $0.65 \pm 0.08$ & NS \\
\hline \multicolumn{5}{|l|}{ Processing traits } \\
\hline Salting loss (\%) & $4.23 \pm 0.16$ & $4.16 \pm 0.17$ & $4.37 \pm 0.14$ & NS \\
\hline Resting loss (\%) & $21.07 \pm 0.79$ & $20.59 \pm 0.70$ & $21.26 \pm 0.63$ & NS \\
\hline Ripening loss (\%) & $31.59 \pm 0.88$ & $31.14 \pm 0.86$ & $32.28 \pm 0.80$ & NS \\
\hline Processing yield (\%) & $68.47 \pm 0.80$ & $69.24 \pm 0.78$ & $68.72 \pm 0.69$ & NS \\
\hline Slicing yield (\%) & $87.30 \pm 0.69$ & $87.27 \pm 0.69$ & $86.48 \pm 0.58$ & NS \\
\hline \multicolumn{5}{|l|}{ Sensory traits ${ }^{1}$} \\
\hline \multicolumn{5}{|l|}{ Semimembranosus muscle } \\
\hline Easy to cut & $4.02^{\mathrm{a}} \pm 0.08$ & $4.45^{\mathrm{b}} \pm 0.08$ & $4.35^{\mathrm{c}} \pm 0.07$ & 0.004 \\
\hline Persistence of fat & $1.85 \pm 0.14$ & $1.54 \pm 0.14$ & $1.78 \pm 0.13$ & 0.09 \\
\hline Pastiness & $1.26^{\mathrm{a}} \pm 0.70$ & $3.26^{\mathrm{b}} \pm 0.69$ & $2.69^{\mathrm{ab}} \pm 0.62$ & 0.039 \\
\hline Tenderness & $3.31^{\mathrm{a}} \pm 0.12$ & $3.99^{b} \pm 0.12$ & $3.89^{\mathrm{b}} \pm 0.11$ & 0.001 \\
\hline \multicolumn{5}{|l|}{ Biceps femoris muscle } \\
\hline Easy to cut & $4.31^{\mathrm{a}} \pm 0.09$ & $4.60^{\mathrm{b}} \pm 0.09$ & $4.52^{\mathrm{ab}} \pm 0.08$ & 0.05 \\
\hline Easy to chew & $3.95^{\mathrm{a}} \pm 0.12$ & $4.47^{\mathrm{b}} \pm 0.12$ & $4.32^{\mathrm{ab}} \pm 0.10$ & 0.008 \\
\hline Pastiness & $1.05 \pm 0.58$ & $2.17 \pm 0.57$ & $1.38 \pm 0.52$ & 0.10 \\
\hline Tenderness & $3.78^{\mathrm{a}} \pm 0.13$ & $4.30^{\mathrm{b}} \pm 0.14$ & $3.99^{\mathrm{a}} \pm 0.12$ & 0.05 \\
\hline
\end{tabular}

${ }^{1} 0-10$ points non-structured scale ( 0 : absence; 10 : maximum intensity).

a,b,c: means within a row without a common letter are significantly different $(\mathrm{p}<0.05)$. significantly higher pHu (5.61 vs. 5.54 for Ile/Val). Our purpose was to evaluate the possible use of the PRKAG3 Ile199Val polymorphism to select animals that perform better in dry-cured ham production without any detrimental effect on technological traits.

The significant associations between sensory traits and the PRKAG3 gene are presented in Table 4. Several gene effects were observed on textural items on both semimembranosus and biceps femoris. The Ile/ $\mathrm{Val}$ heterozygote and the $\mathrm{Val} / \mathrm{Val}$ homozygote were systematically much more tender or easy to chew. Tenderness is an appreciated and desirable characteristic of dry-cured ham, but an excessive degree of proteolysis can reduce meat texture down to a point that impacts consumer acceptability. In this study, PRKAG3 affected pastiness, as Ile/Val heterozygotes differed from Ile/Ile homozygotes. The persistent fat taste tended to be less intense in Ile/Val heterozygotes. A higher tenderness of the product might have modified the time of contact in the mouth, thereby minimising the perception of persistent fat for the semimembranosus muscle.

\subsection{Association between CAST gene polymorphism (loci 249 and 638)} and physicochemical, processing and sensory traits

The chemical parameters and processing yields analysed for CAST249 and CAST638 genotypes are given in Tables 5 and 6. None of the physicochemical traits were affected by CAST genotype at the two loci. These results differed from those reported in Stalder et al. (2005). Salting loss was affected by CAST genotype at locus 249, with Lys/Lys homozygotes presenting lower losses after the salting period. This could not be explained by the higher $\mathrm{pHu}$ in these hams. This slower water dynamics proved persistent, as demonstrated by the lower weight losses found at the resting period and until the end of the processing phase. Indeed, processing yields were higher for Lys/Lys homozygotes, although without differences in slicing ability. For CAST at locus 638, similar results were found for processing traits, except for salting losses. The CAST gene seems to have a positive effect on overall processing yield of dry-cured ham without any concomitant detrimental effects such as reduced sliceability. In fresh meat, Ciobanu et al. (2004) considered the CAST249 Lys/Lys CAST638 Arg/Arg haplotype as optimal in terms of ultimate $\mathrm{pH}$, cooking loss and juiciness. The results are in accordance with the Slovenian study on Kraški pršut showing highest processing losses

Table 5

Association between CAST Lys249Arg genotype and physicochemical, processing and sensory traits of Bayonne dry cured ham. Least squares means \pm standard error. For sensory traits only significant $(\mathrm{p}<0.05)$ or suggestive $(\mathrm{p}<0.10)$ associations are shown.

\begin{tabular}{|c|c|c|c|c|}
\hline & \multicolumn{4}{|c|}{ CAST Arg249Lys genotypes } \\
\hline & $\begin{array}{l}\text { Arg/Arg } \\
n=40\end{array}$ & $\begin{array}{l}\mathrm{Arg} / \mathrm{Lys} \\
n=44\end{array}$ & $\begin{array}{l}\text { Lys/Lys } \\
n=36\end{array}$ & $\mathrm{p}$ Value \\
\hline \multicolumn{5}{|l|}{ Physicochemical traits } \\
\hline Moisture (\%) & $59.67 \pm 0.38$ & $60.44 \pm 0.37$ & $60.41 \pm 0.49$ & NS \\
\hline Chloride (\%) & $5.75 \pm 0.20$ & $5.95 \pm 0.20$ & $5.62 \pm 0.26$ & NS \\
\hline Protein content (\%) & $29.62 \pm 0.33$ & $29.14 \pm 0.32$ & $29.06 \pm 0.44$ & NS \\
\hline Lipid (\%) & $3.29 \pm 0.45$ & $3.32 \pm 0.43$ & $2.75 \pm 0.57$ & NS \\
\hline Proteolysis index (\%) & $28.71 \pm 0.78$ & $29.04 \pm 0.76$ & $28.74 \pm 0.96$ & NS \\
\hline TBARS (mg MDA/kg) & $0.66 \pm 0.10$ & $0.66 \pm 0.10$ & $0.63 \pm 0.13$ & NS \\
\hline \multicolumn{5}{|l|}{ Processing traits } \\
\hline Salting loss (\%) & $4.53^{\mathrm{b}} \pm 0.18$ & $4.36^{\mathrm{b}} \pm 0.17$ & $3.87^{\mathrm{a}} \pm 0.23$ & 0.044 \\
\hline Resting loss (\%) & $22.60^{\mathrm{b}} \pm 0.86$ & $20.77^{\mathrm{a}} \pm 0.80$ & $19.54^{\mathrm{a}} \pm 0.88$ & 0.021 \\
\hline Ripening loss (\%) & $32.74^{\mathrm{b}} \pm 0.91$ & $32.19^{b} \pm 0.88$ & $30.09^{a} \pm 1.08$ & 0.028 \\
\hline Processing yield (\%) & $66.63^{c} \pm 0.83$ & $68.79^{\mathrm{b}} \pm 0.83$ & $71.00^{\mathrm{a}} \pm 1.06$ & 0.01 \\
\hline Slicing yield (\%) & $86.26 \pm 0.73$ & $87.02 \pm 0.72$ & $87.77 \pm 0.99$ & NS \\
\hline
\end{tabular}

Sensory traits ${ }^{1}$

Semimembranosus muscle Tenderness $3.31^{\mathrm{b}} \pm 0.13 \quad 3.93^{\mathrm{a}} \pm 0.12 \quad 3.95^{\mathrm{a}} \pm 0.16 \quad 0.008$

${ }^{10} 0-10$ points non-structured scale ( 0 : absence; 10 : maximum intensity).

a,b,c: means within a row without a common letter are significantly different $(p<0.05)$. 


\section{Table 6}

Association between CAST Arg638Ser genotype and physicochemical, processing and sensory traits of Bayonne dry cured ham. Least squares means \pm standard error. For sensory traits only significant $(\mathrm{p}<0.05)$ or suggestive $(\mathrm{p}<0.10)$ associations are shown.

\begin{tabular}{|c|c|c|c|c|}
\hline & \multicolumn{4}{|c|}{ CAST Ser638Arg genotypes } \\
\hline & $\begin{array}{l}\text { Ser/Ser } \\
n=14\end{array}$ & $\begin{array}{l}\text { Arg/Ser } \\
n=40\end{array}$ & $\begin{array}{l}\text { Arg/Arg } \\
n=66\end{array}$ & $\mathrm{p}$ Value \\
\hline \multicolumn{5}{|l|}{ Physicochemical traits } \\
\hline Moisture (\%) & $59.25 \pm 0.59$ & $60.16 \pm 0.35$ & $60.54 \pm 0.34$ & NS \\
\hline Chloride (\%) & $5.99 \pm 0.30$ & $5.70 \pm 0.19$ & $5.60 \pm 0.18$ & NS \\
\hline Protein content (\%) & $30.05 \pm 0.52$ & $29.35 \pm 0.31$ & $28.94 \pm 0.30$ & NS \\
\hline Lipid (\%) & $3.44 \pm 0.68$ & $2.84 \pm 0.42$ & $3.46 \pm 0.40$ & NS \\
\hline Proteolysis index (\%) & $28.77 \pm 1.13$ & $29.50 \pm 0.73$ & $28.32 \pm 0.72$ & NS \\
\hline TBARS (mg MDA/kg) & $0.70 \pm 0.16$ & $0.63 \pm 0.10$ & $0.67 \pm 0.09$ & NS \\
\hline \multicolumn{5}{|l|}{ Processing traits } \\
\hline Salting loss (\%) & $4.39 \pm 0.28$ & $4.06 \pm 0.16$ & $4.31 \pm 0.16$ & NS \\
\hline Resting loss (\%) & $21.13 \pm 1.04$ & $20.35 \pm 0.72$ & $21.43 \pm 0.76$ & NS \\
\hline Ripening loss (\%) & $32.49 \pm 1.25$ & $31.36 \pm 0.86$ & $31.16 \pm 0.84$ & NS \\
\hline Processing yield (\%) & $68.36 \pm 1.25$ & $69.89 \pm 0.79$ & $68.18 \pm 0.75$ & NS \\
\hline Slicing yield (\%) & $87.86 \pm 1.17$ & $86.90 \pm 0.70$ & $86.30 \pm 0.65$ & NS \\
\hline \multicolumn{5}{|l|}{ Sensory traits ${ }^{1}$} \\
\hline \multicolumn{5}{|l|}{ Whole slice } \\
\hline Total odour intensity & $32.49 \pm 1.25$ & $31.36 \pm 0.86$ & $31.16 \pm 0.84$ & 0.06 \\
\hline Pungent odour & $0.61 \pm 0.12$ & $0.38 \pm 0.07$ & $0.50 \pm 0.06$ & 0.08 \\
\hline \multicolumn{5}{|l|}{ Semimembranosus muscle } \\
\hline Rancid flavour & $0.11^{\mathrm{a}} \pm 0.05$ & $0.26^{\mathrm{b}} \pm 0.03$ & $0.19^{\mathrm{ab}} \pm 0.03$ & 0.007 \\
\hline Tenderness & $3.61^{\mathrm{a}} \pm 0.19$ & $3.99^{\mathrm{b}} \pm 0.12$ & $3.59^{\mathrm{a}} \pm 0.11$ & 0.014 \\
\hline
\end{tabular}

${ }^{1} 0$-10 points non-structured scale ( 0 : absence; 10 : maximum intensity).

a,b : means within a row without a common letter are significantly different $(p<0.05)$.

for CAST249 Arg/Arg in the case of one producer (Škrlep, ČandekPotokar, Santé-Lhoutellier, \& Gou, 2011). Moreover the results on the impact of the CAST gene are also consistent with Stalder et al. (2005), although these authors did not separately evaluate the two loci (i.e. 249 and 638). Stalder et al. (2005) found no effect of CAST638 on any of the widely-measured meat quality traits, but they did report a lower muscle temperature in Arg/Arg homozygotes which could slow down and inactivate post-mortem $\mathrm{pH}$ drop. This lowering of temperature may be due to the less-rounded ham shape or lighter ham weight. These conformational traits were not measured in the present study.

Table 5 presents only one significant association between sensory traits and CAST gene at locus 249, and only for the semimembranosus muscle. Arg/Arg homozygosity was associated with lower tenderness, and there are no other items that showed significant differences. Taking all the above points into consideration, the results suggest that the salt reduction in this study did not impair the final product quality, and that CAST Lys/Lys has a positive overall effect on processing traits.

Table 6 presents the significant associations between sensory traits and CAST Ser638Arg. Ser/Ser homozygotes tended to be associated with higher taste intensity and marked pungent odour. The pungent item can be described as an irritating sensation that was clearly perceptible by the panel. The proteolysis process in drycured ham leads to free amino acids whose subsequent sensory impact will depend on the amino acid side-chain residues. RoudotAlgaron (1996) published a review summarising amino acid and peptide tastes. Briefly, isoleucine, phenylalanine, valine, leucine and proline, through their hydrophobicity, contribute to the development of pungency. The present results combined with those of Škrlep et al. (2010) point to a higher content of potentially bitter or pungent amino acids in the dry-cured ham from CAST249 Arg/Lys and $\mathrm{Arg} / \mathrm{Arg}$ pigs. The gene effect was significant for the rancid item in the SM muscle. This result is difficult to explain per se, since TBARS did not differ, but since moisture content was lower in the dry-cured ham from CAST638 Ser/Ser animals compared to Ser/Arg and Arg/Arg animals, the consequently higher salt concentration could have masked the development of rancid taste. Only two salt $\times$ gene interactions were found, both with CAST638. Taste intensity was stronger with CAST638 Ser/Ser, but only in normal-salt-content dry-cured ham. Moreover, in these dry-cured hams (normal salt/CAST638 Ser/Ser), pungent odour was more than doubled. The more intense taste might be due to this more marked unpleasant sensation. Salt reduction effectively limited this gene effect.

\subsection{CAST haplotype associations}

To study the CAST haplotype associations, combined CAST249CAST638 genotypes were used which were represented by a minimum of five animals, avoiding those animals that were heterozygotes for both CAST249 and CAST638. Thus the following genotypes were used: 249Lys/249Lys-638Arg/638Arg (C1), 249Lys/249Arg-638Arg/ 638Arg (C2), 249Arg/249Arg-638Arg/638Arg (C3), 249Arg/249Arg638Arg/638Ser (C4) and 249Arg/249Arg-638Ser/638Ser (C5). These genotypes allowed estimation of three CAST haplotype differences: 249Lys-638Arg vs. 249Arg-638Arg, 249Lys-638Arg vs. 249Arg-638Ser and 249Arg-638Arg vs. 249Arg-638Ser.

To estimate each haplotype difference, different individual contrasts were used by considering the animals as having 0,1 or 2 copies of each haplotype (Table 5). The arithmetic mean of the individual contrasts does not take into account the fact that the number of animals was different for each CAST249-CAST638 genotype, which implies that each individual contrast has a different error. If it is assumed that the variability in the population was the same in all groups $\left(\sigma_{o}\right)$, the square error for each individual contrast can be estimated as:

$s e=\frac{n_{i}+n_{j}}{n_{i} \cdot n_{j}} \cdot \sigma_{o}^{2}$

where $n_{i}$ and $n_{j}$ are the number of animals of the combined CAST249CAST638 genotype contributing to the contrast.

A weighted mean contrast was calculated for each haplotype difference using $\left(n_{i} \cdot n_{j}\right) /\left(n_{i}+n_{j}\right)$ as the weight for each contrast contributing to the mean contrast (Table 7). In this weighted mean contrast set-up, the genotype counting more animals makes a greater contribution to the final average than the genotype counting fewer animals.

Analysis of the CAST haplotypes (Table 8) showed that haplotypes tended to differ on one physicochemical trait: moisture. Haplotypes 249Arg/638Arg and Lys249/Arg638 had the highest moisture content. Among sensory traits, tenderness of SM and the ease-of-cutting of SM and BF muscles were significantly affected by haplotypes, with haplotypes 249Lys/638Arg and Lys249/Arg638 showing the highest tenderness. For rancidity, haplotype 249Lys/638Arg led to the highest value in dry-cured ham. Processing traits also differed with haplotypes: 249Lys/638Arg showed lower salting loss, lower resting loss and higher processing yields compared to $249 \mathrm{Arg} / 638 \mathrm{Arg}$ and $249 \mathrm{Arg} / 638 \mathrm{Ser}$.

Table 7

Contrasts constructed with CAST249-CAST638 genotype estimates to estimate CAST haplotype differences.

\begin{tabular}{lllllc}
\hline Haplotype difference & \multicolumn{5}{l}{ CAST249-CAST638 } \\
\cline { 2 - 6 } & C1 & C2 & C3 & C4 & C5 \\
\hline Number of hams & a \\
249Lys-638Arg vs. 249Arg-638Arg & 36 & 30 & 14 & 26 & 14 \\
$\quad$ Contrast & 1 & -1 & 0 & 0 & 0 \\
249Lys-638Arg vs. 249Arg-638Ser & & & & & \\
$\quad$ Contrast 1 & 0.5 & 0 & 0 & 0 & -0.5 \\
$\quad$ Contrast 2 & 0 & 1 & 0 & -1 & 0 \\
$\quad$ Weighted mean contrast & 0.21 & 0.58 & 0 & -0.58 & -0.21 \\
249Arg-638Arg vs. 249Arg-638Ser & & & & & \\
$\quad$ Contrast & 0 & 0 & 0 & 1 & -1
\end{tabular}

a C1: 249Lys/249Lys-638Arg/638Arg; C2: 249Lys/249Arg-638Arg/638Arg; C3: 249Arg/ 249Arg-638Arg/638Arg; C4: 249Arg/249Arg-638Arg/638Ser; C5: 249Arg/249Arg638Ser/638Ser. 
Table 8

Differences between CAST haplotypes compared in this study (H1: 249Lys-638Arg, H2: 249Arg-638Arg, H3: 249Arg-638Ser) for those attributes with significant $(\mathrm{p}<0.05)$ or suggestive $(\mathrm{p}<0.10)$ association with CAST249-CAST638 genotype. SE: standard error.

\begin{tabular}{|c|c|c|c|c|}
\hline & & \multicolumn{3}{|c|}{ Haplotype differences } \\
\hline & & $\mathrm{H} 1-\mathrm{H} 2$ & $\mathrm{H} 1-\mathrm{H} 3$ & $\mathrm{H} 2-\mathrm{H} 3$ \\
\hline \multirow{3}{*}{$\begin{array}{l}\text { Moisture (\%) } \\
\qquad(p=0.0835)\end{array}$} & Estimate & 0.01 & 0.51 & 0.92 \\
\hline & SE & 0.40 & 0.26 & 0.55 \\
\hline & p Value & 0.977 & 0.052 & 0.100 \\
\hline \multirow{3}{*}{$\begin{array}{l}\text { Easy-to-cut } \mathrm{SM}^{\mathrm{a}} \\
\quad(\mathrm{p}=0.0379)\end{array}$} & Estimate & 0.040 & 0.134 & 0.209 \\
\hline & SE & 0.099 & 0.063 & 0.134 \\
\hline & p Value & 0.688 & 0.037 & 0.122 \\
\hline \multirow{3}{*}{$\begin{array}{l}\text { Tenderness SM }{ }^{a} \\
\quad(p=0.0008)\end{array}$} & Estimate & 0.027 & 0.254 & 0.379 \\
\hline & SE & 0.125 & 0.081 & 0.171 \\
\hline & p Value & 0.829 & 0.003 & 0.033 \\
\hline \multirow{3}{*}{$\begin{array}{l}\text { Rancid flavour } \mathrm{SM}^{\mathrm{a}} \\
\qquad(\mathrm{p}=0.0396)\end{array}$} & Estimate & 0.01 & -0.01 & 0.16 \\
\hline & SE & 0.04 & 0.02 & 0.05 \\
\hline & p Value & 0.868 & 0.573 & 0.004 \\
\hline \multirow{3}{*}{$\begin{array}{l}\text { Easy-to-cut BF } \\
\qquad(p=0.0943)\end{array}$} & Estimate & 0.05 & 0.12 & 0.28 \\
\hline & SE & 0.11 & 0.07 & 0.15 \\
\hline & $\mathrm{p}$ Value & 0.660 & 0.087 & 0.067 \\
\hline \multirow{3}{*}{$\begin{array}{l}\text { Salting loss (\%) } \\
\qquad(p=0.0159)\end{array}$} & Estimate & -0.50 & -0.11 & -0.33 \\
\hline & SE & 0.20 & 0.13 & 0.26 \\
\hline & $\mathrm{p}$ Value & 0.015 & 0.405 & 0.214 \\
\hline \multirow{3}{*}{$\begin{array}{l}\text { Resting loss }(\%) \\
\quad(p=0.0062)\end{array}$} & Estimate & -1.23 & -1.01 & -0.78 \\
\hline & SE & 0.64 & 0.45 & 0.88 \\
\hline & p Value & 0.063 & 0.033 & 0.381 \\
\hline \multirow{3}{*}{$\begin{array}{l}\text { Processing yield (\%) } \\
\qquad(\mathrm{p}=0.0008)\end{array}$} & Estimate & 2.20 & 1.14 & 1.53 \\
\hline & SE & 0.83 & 0.55 & 1.14 \\
\hline & p Value & 0.011 & 0.045 & 0.186 \\
\hline
\end{tabular}

SM: semimembranosus muscle; BF: biceps femoris muscle.

a $0-10$ points non-structured scale (0: absence; 10 : maximum intensity).

\section{Conclusion}

This study demonstrated differences in the impacts of PRKAG3 and CAST genes in the selected hams, and underlined the important effects of the CAST gene at loci 249 and 638 on several fresh and drycured ham traits in the pig line used. However, the significant linkage disequilibrium between CAST polymorphisms observed in the population weakens, to some extent, the impact of the study. The PRKAG3 Ile/Val heterozygote was associated with suitable sensory properties. The 249Lys/638Arg haplotype presented the highest scores for sensory and processing traits whatever the salt content. In conclusion, this study identified the genotype (PRKAG3 and CAST) that is best adapted to producing French Bayonne dry-cured hams with reduced salt content without any deleterious effects on processing and sensory qualities.

\section{Acknowledgments}

This work was funded by the European Commission under the 6th Framework Programme for RTD (TRUEFOOD - "Traditional United Europe Food" - Integrated project FOOD-CT-2006-016264). The information in this document reflects only the author's views and the Community is not liable for any use that may be made of the information contained therein.

\section{References}

Adamsen, C., Moller, J., Parolari, G., Gabba, L., \& Skibsted, L. H. (2006). Changes in $\mathrm{Zn}$-porphyrin and proteinous pigments in Italian dry-cured ham during processing and maturation. Meat Science, 74, 373-379.

Arnau, J., Maneja, E., Guerrero, L., \& Monfort, J. M. (1993). Phosphate crystals in dry cured ham. Fleischwirtschaft, 8, 875-876.

Benedini, R., Parolari, G., Toscani, T., \& Virgili, R. (2012). Sensory and texture properties of Italian typical dry-cured hams as related to maturation time and salt content. Meat Science, 90, 431-437.

Ciobanu, D. C., Bastiaansen, J., Lonergan, S. M., Thomsen, H., Dekkers, J. C. M., Plastow, G. S., et al. (2001). Evidence for new alleles in the protein kinase adenosine monophosphate-activated g3-subunit gene associated with low glycogen content in pig skeletal muscle and improved meat quality. Genetics, 159, 1151-1162.

Ciobanu, D. C., Bastiaansen, J., Malek, M., Helm, J., Woolard, J., Plastow, G. S., et al. (2004). New alleles in calpastatin gene are associated with meat quality traits in pigs. Journal Animal Science, 82, 2829-2839.

Fontanesi, L., Davoli, R., Nanni Costa, L., Berettia, F., Scotti, E., Tazzoli, M., Tassone, F., Colombo, M., Buttazzoni, L., \& Russo, V. (2008). Investigation of candidate genes for glycolytic potential of porcine skeletal muscle: Association with meat quality and production traits in Italian Large White pigs. Meat Science, 80, 780-787.

Garnier, J., Klont, R., \& Plastow, G. (2003). The potential impact of current animal research on the meat industry and consumer attitudes towards meat. Meat Science, $63,79-88$.

Graiver, N., Pinotti, A., Califano, A., \& Zaritzky, N. (2006). Diffusion of sodium chloride in pork tissue. Journal of Food Engineering, 77, 910-918.

Kerese, I., \& Chalmers, R. A. (1984). Methods of protein analysis. E. Horwood.

Martin, L., Cordoba, J., Antequera, T., Timon, M., \& Ventanas, J. (1998). Effects of salt and temperature on proteolysis during ripening of Iberian ham. Meat Science, 49, 145-153.

Motilva, M., \& Toldrá, F. J. (1993). Effect of curing agents and water activity on pork muscle and adipose subcutaneous tissue lipolytic activity. Zeitschrift fur Lebensmittel, 196, 228-232.

Otto, G., Roehe, R., Looft, H., Thoelking, L., Knap, P. W., Rothschild, M. F., et al. (2007). Associations of DNA markers with meat quality traits in pigs with emphasis on drip loss. Meat Science, 75, 185-195.

Parolari, G., Virgili, R., \& Schivazappa, C. (1994). Relationship between cathepsin B activity and compositional parameters in dry-cured hams of normal and defective texture. Meat Science, 38, 117-122.

Plastow, G., Carrion, D., Gil, M., García-Regueiro, J. A., Font-Furnols, M., Gispert, M., et al. (2005). Quality pork genes and meat production. Meat Science, 70, 409-421.

Ramos, A. M., Serenius, T. V., Stalder, K. J., \& Rothschild, M. F. (2007). Phenotypic correlations among quality traits of fresh and dry cured hams. Meat Science, 77, 579-587.

Ripolles, S., Campagnol, P., Armenteros, M., Aristoy, M. C., \& Toldrá, F. (2011). Influence of partial replacement of $\mathrm{NaCl}$ with $\mathrm{KCl}, \mathrm{CaCl} 2$ and $\mathrm{MgCl} 2$ on lipolysis and lipid oxidation in dry-cured ham. Meat Science, 89, 58-64.

Rosell, C., \& Toldrá, F. (1998). Comparison of muscle proteolytic and lipolytic enzyme levels in raw hams from Iberian and white pigs. Journal Science Food Agriculture, 76, 117-122.

Roudot-Algaron, F. (1996). Le gout des acides aminés, des peptides et des protéines: exemples de peptides sapides dans les hydrolysats de caséine. Lait, 76, 313-348.

Santé-Lhoutellier, V., Candek-Potokar, M., Gou, P., Dutertre, C., \& Robert, N. (2009). Impact of salt reduction in Bayonne dry cured ham on processing yields and slicing ability. Proceedings of the 55th International Congress of Meat Science and Technology, 15-20th August, Copenhagen, Denmark.

Sárraga, C., Gil, M., Arnau, J., Monfort, J. M., \& Cussó, R. (1989). Effect of curing salt and phosphate on the activity of porcine muscle proteases. Meat Science, 25(4), 241-249.

Shahidi, F., Rubin, J., Diosady, L., \& Wood, D. (1985). Effect of sulphanilamide on the TBA values of cured meats. Journal of Food Science, 50, 274-275.

Škrlep, M., Čandek-Potokar, M., Žlender, B., Robert, N., Santé-Lhoutellier, V., \& Gou, P. (2012). PRKAG3 and CAST genetic polymorphisms and quality traits of dry-cured hams - III. Associations in Slovenian dry-cured ham Kraški pršut and their dependence on processing. Meat Science, http://dx.doi.org/10.1016/j.meatsci.2012.06.021.

Škrlep, M., Čandek-Potokar, M., Kavar, T., Žlender, B., Hortós, M., Gou, P., et al. (2010). Association of PRKAG3 and CAST genetic polymorphisms with traits of interest in dry-cured ham production: Comparative study in France, Slovenia and Spain. Livestock science, $128,60-68$.

Škrlep, M., Čandek-Potokar, M., Santé-Lhoutellier, V., \& Gou, P. (2011). Dry ham "Kraški pršut" seasoning losses as affected by PRKAG3 and CAST polymorphisms. Italian Journal of Animal Science, 10, 27-32.

Stalder, K., Rothshild, M., \& Lonergan, S. (2005). Associations between two gene markers and indicator traits affecting fresh and dry cured ham processing quality. Meat Science, 69, 451-457.

Stefanon, B., Susmel, P., Floris, R., Graziosi, G., Braglia, S., Davoli, R., et al. (2004). A new approach in association study of single nucleotide polymorphism of genes for carcass and meat quality traits in commercial pigs. Italian Journal of Animal Science, 3(2), 177-189.

Théron, L., Chevarin, L., Robert, N., Dutertre, C., \& Santé-Lhoutellier, V. (2009). Time course of peptide fingerprints in semimembranosus and biceps femoris muscles during Bayonne ham processing. Meat Science, 82, 272-277.

Théron, L., Sayd, T., Pinguet, J., Chambon, C., Robert, N., \& Santé-Lhoutellier, V. (2011). Proteomic analysis of semimembranosus and biceps femoris muscles from Bayonne dry-cured ham. Meat Science, 88, 82-90.

Thorarinsdottir, K. A., Arason, S., Geirsdottir, M., Bogason, S. G., \& Kristbergsson, K. (2009). Changes in myofibrillar proteins during processing of salted cod (Gadus morhua) as determined by electrophoresis and differential scanning calorimetry. Food Chemistry, 77, 377-385.

Toldrá, F., \& Flores, M. (1998). Role of muscle proteases and lipases in flavor development during processing of dry cured ham. Critical Review in Food Science, 69, 451-457.

Virgili, R., Parolari, G., Schivazappa, C., Bordini, C. S., \& Borri, M. (1995). Sensory and texture quality of dry-cured ham as affected by endogenous cathepsin B activity and muscle composition. Journal Food Science, 60, 1183-1186.

Virgili, R., Schivazappa, C., Parolari, G., Bordini, C. S., \& Degni, M. (1998). Protease in fresh pork muscle and their influence on bitter taste formation in dry-cured ham. Journal of Food Biochemistry, 22, 53-63. 